\title{
The Geo-economic Gravity Systems as a Tool for the Analysis of Socio-Economic Polarization in a Society: Country Case Study and Geographic Information Modelling Explain Long-term Transformation Potential towards Increased Regional Attractiveness and Efficiency
}

\author{
John Karkazis \\ Prof., Dean of Business School, \\ University of the Aegean, \\ Chios, Greece \\ Georgios C. Baltos \\ Ph.D.(c), Business School, \\ University of the Aegean, \\ Chios, Greece
}

Doi: 10.2478/ajis-2018-0054

\begin{abstract}
In this paper the concept of the "Geo-Economic Gravity System" will be discussed as a methodological tool in regard with the key issue of "regional efficiency", as well as a modeling tool in the effort to face relevant socio-economic problems. As a case study, the fierce opposition between oriental and westernoriented political powers, other words neo-ottomans versus kemalists in the Turkish society, is being respectively examined. The Geo-economic Gravity Systems explain the socio-economic rifts, heading back to the 90's and demonstrating the multiple and prevailing societal polarization. On its second part, however, this study exhibits that, in the aftermath of the R.T. Erdogan's governments, despite that the political dichotomy lines remain, at least the severe economic disparities have been smoothed due to policies, incentives and infrastructure investments accomplished. The analysis of Turkey's internal geoeconomic trends offers notable insight into the mechanism controlling in general the regional socioeconomic attractiveness and efficiency. Consequently, such an analysis can remarkably contribute in the research of the spatial dimension as a catalyst for emerging development opportunities in any country.
\end{abstract}

Keywords: Regional Efficiency, Geo-Economic Models, Turkey, Social Polarization

\section{Introduction}

In line with the dynamic changes in the Middle East, mainly concerning the Syrian civil war, an overwhelming round of debates have emerged among the international think tanks involving the majority of neighboring countries and stakeholders in the region. Especially for Turkey, such a discussion frequently results in geopolitical approaches and interpretations that are based on the long lasting and fiercely opposition between oriental and western-oriented political powers, "Anatolian" mentality versus military control, "neo-ottomans" versus "kemalists", etc. The rifts of the Turkish society are also combined with socio-political traditions of excessive and unlimited respect 
to the state powers along with a tendency for worshipping the powerful and charismatic leaders. The analysis ${ }^{1}$ draws data from the latest decades of the Turkish politics arena, comparing the longlast kemalist dominance to the political Islam version of the currently governing party AKP (Karkazis, Baltos \& Vidakis 2017).

On one hand, the gaps among socio-political groups of citizens not only remain but deepen, against what was ambitiously expected in the early 2000's, that an Islamic party could unify the nation by spreading the liberalism that was missing for decades on the Turkish political stage (Sajjad and Javaid 2016). It is true that the society is being transformed, the politico-economic gravity centers have been re-positioned on the map of ideologies and interests served, but numerous researchers claim that the shift heads to the wrong direction. On the other hand, however, this study exhibits that, in the aftermath of the R.T. Erdogan's governments, despite that the political dichotomy lines remain, at least the severe economic disparities have been smoothed due to specific policies, incentives and infrastructure investments accomplished (Ferguson 2017).

A limitation of this research is that it covers and verifies the successful economic outcome over a long period of AKP governments but does not enter into the threats of destabilization that current developments imply. Both the research question and the added value achieved emphasize on the significant opportunities created, deployed and implemented in the economic environment. The leverage of the opportunities in discussion requires relevant policies, practices, structural reforms and investments (Stellakou and Karkazis 1992). In this context, the analysis of Turkey's socio-economic profile and its internal geo-economic trends could offer valuable insight into the discussions about the mechanisms controlling in general the regional socio-economic attractiveness, i.e. the "regional efficiency". Such a study may greatly contribute in the analysis of the spatial characteristics of any hidden growth potential in developing countries.

In particular, the "Geo-Economic Gravity System" is being applied in order to interpret the key application of "regional efficiency" in the Turkish political environment over the latest decades (Karkazis 2012). The following analysis briefly presents selected regional efficiency models, the "Economic Gravity System", the regional socio-economic profile of Turkey along with its GeoEconomic Gravity Systems.

\section{The Methodology of Regional Efficiency Models}

At the background of the policies in discussion the main driver is no other but the enhancement of a state' administrative units, provincial, regional or national, to deploy capabilities in terms of infrastructure, human and natural resources towards socio-economic sustainability and growth.

The geographic position of regions and provinces, among other factors, determines comparative advantages that might have not been fully or merely exploited; in this context, for example, any new infrastructure may boost regional growth. Modeling such "efficient regions" is a very difficult process, usually based on the systemic and/or the cost approach.

\subsection{The systemic approach}

That includes "Frontier analysis models (see Fig. 1) and Regional image attractiveness models" (Karkazis 2012).

${ }^{1}$ This paper elaborates and updates on the results of multiple applications of the Geographic Information System: Ptolemeos III, supported by Constantine Porphyrogenetus International Association (Karkazis 2012). 


\section{Frontier analysis models}

Frontier analysis models express regional efficiency through an input-output systemic structure.

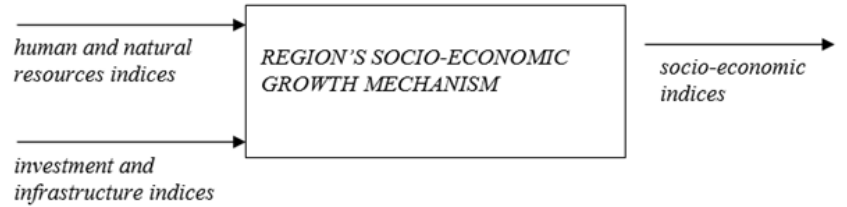

Fig. 1. Frontier analysis models (Karkazis 2012)

The regional efficiency is generally perceived as the best exploitation of available resources in order to produce socio-economic growth. For instance, Karkazis and Thanassoulis (Karkazis and Thanassoulis 1998) assessed the effectiveness of regional development policies in Northern Greece using the specialized linear programming-based method Data Envelopment Analysis (DEA), whereas they concluded in the following systemic structure, as it appears at Fig. 2 below:

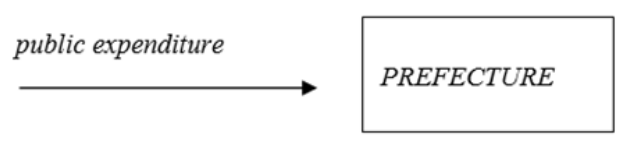
attraction

Fig. 2. Karkazis and Thanassoulis approach (Karkazis and Thanassoulis 1998)

Additional sources concerning an introduction to DEA can be found in R.W. Eglese (Eglese and Hendry 1990) and A. Charnes (Charnes et al. 1997). A. Athanassopoulos and J. Karkazis (Athanassopoulos and Karkazis 1997) also further discussed the concept of "Systemic Duality" in regard with regional growth. The application, for instance, of the DEA methodology, especially for Turkey in the 1990's, produced a categorization of the provinces in the four groups of the Table 1 below:

Table 1. Categorization of the Turkish provinces with DEA methodology (Anemodouras et al.)

\begin{tabular}{|l|l|}
\hline Model provinces (maximum grade) & Kocaeli and Zoguldak \\
\hline Highly efficient & $\begin{array}{l}\text { Istanbul, Kirklareli, Sakarya, Canakkale, } \\
\text { Izmir, Manisa, Mugla and Aydin }\end{array}$ \\
\hline \multirow{2}{*}{ Moderately efficient } & $\begin{array}{l}\text { Balikesir, Kutahya, Usak, Denizli, Burdur, } \\
\text { Karaman, Icel, Adana, Osmaniye, } \\
\text { Kahraman-Maras, Bolu, Ankara, Nevsehir } \\
\text { and Artvin }\end{array}$ \\
\hline Highly inefficient & $\begin{array}{l}\text { The majority of the Eastern Region and } \\
\text { the Black Sea Region provinces }\end{array}$ \\
\hline
\end{tabular}

Regional image attractiveness models, on the other hand, focus on the socio-economic profile of a region, and primarily on its attractiveness in terms of sourcing capital and labor. V. Stellakou and J. Karkazis (Stellakou and Karkazis 1992) evaluated the long-term viability of infrastructure investments in the North Aegean Region, while V. Angelis and C. Dimaki (Angelis and Dimaki 1998) analyzed further the trends of selected areas' images.

On the same subject, L. Hunter and L. Reid (Hunter and Reid 1968) and P. M. Townroe (Townroe 1979) added value and insightful research. 


\subsection{The cost approach}

In the cost approach certain areas are capable of attracting supply, transportation and construction center facilities at a level that characterizes them as "Geo-Economic Gravity Areas" and "GeoEconomic Gravity Centers" respectively (Karkazis 2007).

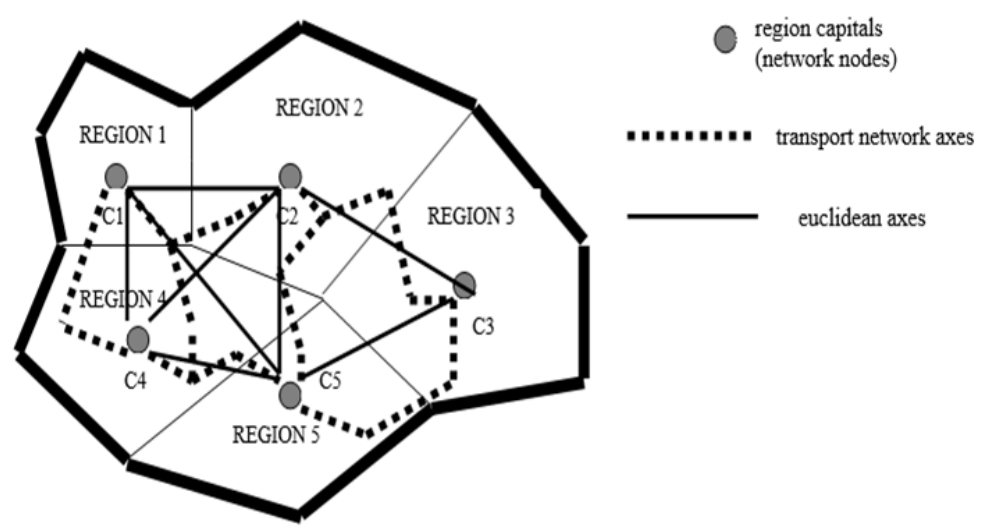

Fig. 3. The n-Facilities Location Problem (Karkazis 2012)

\section{The Generic form of a Geo-economic Gravity Model}

In general, the n-Facilities Location Problem regards "the location of $\mathrm{n}$ non-competing supply facilities in a geographical area that will fully cover the demand for services (public sector or social type facilities) or commodities (private sector or economic type facilities) of a system of demand poles at a minimum, fixed and transport, cost" (Karkazis and Boffey 1981). The term "demand pole" plays basic role in this modeling process, as it is presented at the Fig. 3 above (Townroe 1979). The demand poles of an area are spatially represented by a "central" point, for example the capital of the province, region or state (Boffey and Karkazis 1984). The demand of regions/provinces can be represented by summary measures like population, GDP, imports, etc. (Weiszfeld 1937).

\section{The Regional Socio-economic Profile of Turkey}

According to the Turkey's territorial units of reference eighty one administrative units called provinces were taken into account. The source of the data presented is the State Institute of Statistics, then Turkish Statistical Institute. In order to configure the respective geo-economic gravity systems of the country it is helpful to present the research results categorized as social, economic and industrial.

\subsection{The Social Gravity System of Turkey}

With regard to the period 1990-2001, Ankara was the simple Social Gravity Center of Turkey, exhibiting minor westward movement (see maps 1,2 and 3). The following mapping depictions were based on data regarding the population of the provinces of Turkey in 1990 (thousands of inhabitants), as well as the population of the provinces of Turkey in 2001. 


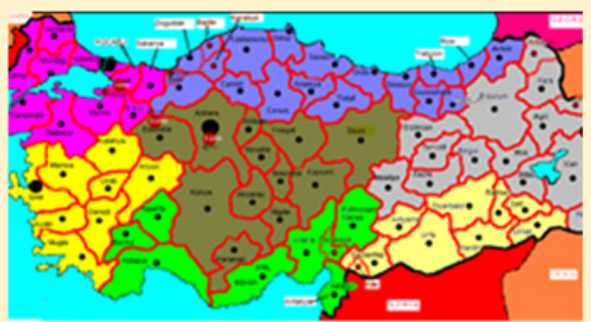

MAP 1. The simple Social and Economic Gravity Centers in 2001 and the simple Industrial Gravity Center of Turkey in 1993

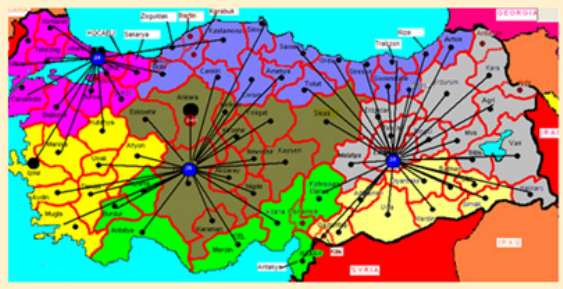

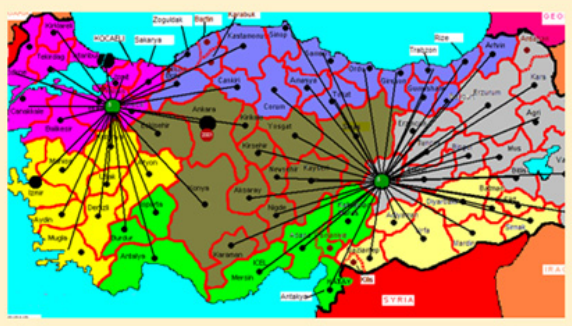

MAP 2. The dual Social Gravity System of Turkey

MAP 3. The triple Social Gravity System of Turkey

Fig. 5. The dual and triple Social Gravity Systems (Karkazis 2012)

\subsection{The Economic Gravity System of Turkey}

With regard to the period 1990-2001, Eskisehir province was the simple Economic Gravity Center, exhibiting minor westward movement (see maps 4 and 5). The following mapping depictions were based on data regarding the GDP of the provinces of Turkey in 1990 (billions of Turkish Lira), as well as the GDP of the provinces of Turkey in 2001.

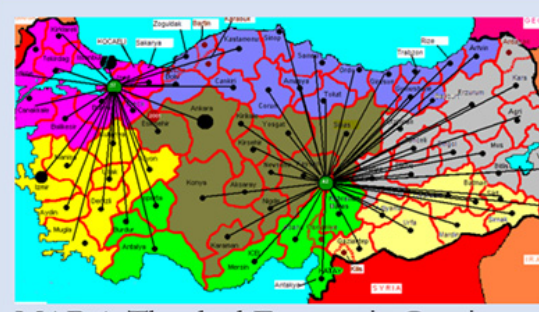

MAP 4. The dual Economic Gravity System of Turkey

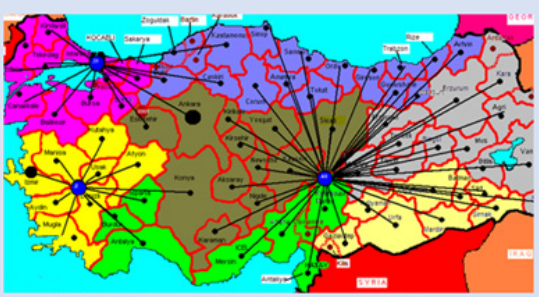

MAP 5. The triple Economic Gravity System of Turkey

Fig. 6. The dual and triple Social Gravity Systems (Karkazis 2012)

\subsection{The Industrial Gravity System of Turkey}

In 1993, Kocaeli province was the simple Industrial Gravity Center of Turkey, exhibiting minor westward movement (see maps 6 and 7). The following Mapping depictions were based on data regarding the Manufacturing Value Added of the provinces of Turkey in 1993 (billions Turkish Lira). 


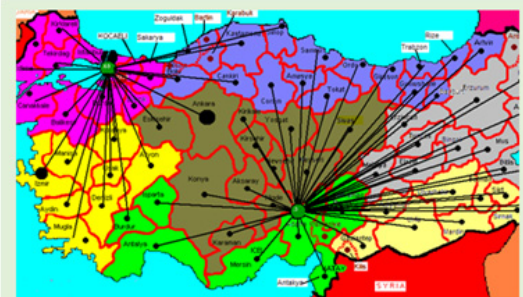

MAP 6. The dual Industrial Gravity System of Turkey

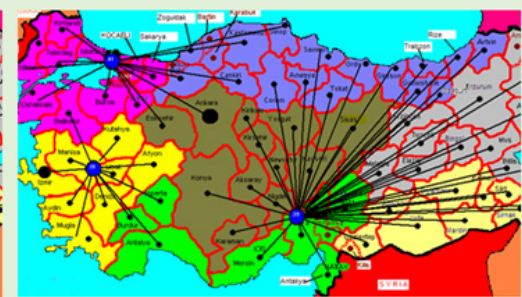

MAP 7. The triple Industrial Gravity System of Turkey

Fig. 7. The dual and triple Social Gravity Systems (Karkazis 2012)

\section{Updated Case Study \& Statistical Review}

In the context of a brief case study, this study also examined the roads network construction at a regional level, but over a sequence of a dozen of years divided to the two "competing" kemalist and post-kemalist political regimes. Relevant data were taken from the Organization for Economic Cooperation and Development (OECD) (OECD 2017). Regions editions, United Nations Development Programme (UNDP 2016) (Human Development Index) and Turkish Statistical Institute were also helpful for comprehending the constructions development (Turkish Statistical Institute 2017). This pilot experiment underlines the contribution of the regions to the economic progress, taking into account the elections' results per region as well as the distribution of the resources available to several regions according to their political identity and elections' preferences (Oguz and Pinarcioglu 2006). The roads network is an indicator characteristically underlining the regional disparities, reflecting in parallel institutional changes among developing regions (OECD, 2011).

In order to find out if there were any significant changes over time and whether they were different according to the political regime changes, mixed linear models were employed. Therefore, the regression equation included terms for political regime and time. Adjusted regression coefficients $(\beta)$ with standard errors (SE) were computed from the results of the mixed models. These models are particularly useful in longitudinal studies where repeated measurements are made on the same statistical units (Ciddi 2009). The length of the roads network was the dependent variable that was measured annually from 1995 to 2012. Interactions of the political regime and time were tested in order to investigate if the effect of the political regime on dependent variables was different or consistent over time. All reported $\mathrm{p}$ values were two-tailed. Statistical significance was set at $\mathrm{p}<0.05$; analyses were conducted using STATA statistical software (version 9.0) (Karkazis, Baltos and Balodis 2018). Fig. 8 below presents the results in brief.

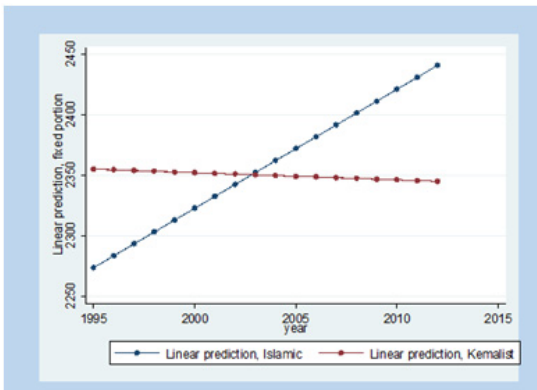

Results

The length of the Road network increased significantly during the eleven-year time period and a significant interaction effect of time with the political regime was found indicating that in case of more Islamicoriented regions there was a greater increase in Road network length as compared with regions where kemalism prevails.

Fig. 8. Linear prediction on the provincial roads network length over the period 1995-2012 for Islamic vs Kemalist political regimes. 


\section{Conclusions and Policy Implications}

Given the average EU statistics, Turkey demonstrated for many decades a high level of regional disparities. These were mainly identified at the provinces of Eastern and Southeast regions along with some provinces at the Black Sea Region provinces. The disparities in discussion are reflected in multiple socio-economic distortions and administrative deficiencies (Karkazis 2012). Over the latest years, however, Turkey has introduced long-term investments in order to meet the weaknesses of certain gravity centers, like the Southeastern Anatolia Project, the so-called GAP, and a legal framework stimulating the employment and investments environment (see the famous Law 4325/1998) (Betcherman, Daysal, and Pagés 2010).

Istanbul and Izmir were definitely the major traditional poles in terms of socio-economic progress. Ankara followed third, growing up in parallel with the establishment of the Turkish State in the $20^{\text {th }}$ century. Especially during the latest thirty years, the analysis highlights a fourth pole emerged in the province of Adana at the southeastern Turkey. The developing characteristics are concentrated on those four poles, which maintain an attractive socio-economic profile, while the rest of the surrounding provinces were exhibiting less attractivity.

During the so called Kemalist period plenty of provinces were functioning as outliers, initially lacking the infrastructure and the socio-economic profile needed for their transformation to development poles. After the pivotal year of 2002, however, many centers like Malatya exploited their strong geo-economic advantages as well as the necessary capability to act as the "Development Gate to the Eastern and Southeast Regions".

The geographically peripheral position of the identified above three Gravity Centers, where all three of them were lying to the west and significantly away of the geographical center of the country is briefly titled as a general "dual Geo-Economic Gravity System" (Karkazis 1999). Two areas appear to be accordingly advantageous:

- Bursa-Istanbul-Kocaeli triangle, i.e. the western center for all (social, economic and industrial) dual Gravity Systems examined and

- Kayseri-Malatya-Adana triangle, i.e. the eastern center for all (social, economic and industrial) dual Gravity Systems examined (Karkazis 2012).

The strategic changes of Turkish society due to the impetus for reforms and revival of the socalled neo-ottoman characteristics is being projected as the appearance of a general triple GeoEconomic Gravity System versus the prevailing in the past dual one. The sectoral improvements accomplished were mainly associated with distribution (supply) activities, huge constructions and financial leverages exhibiting business incentives, state aid and business-friendly consensus in the local societies. The areas having the necessary advantages to accommodate, as they actually did, such centers were:

- Istanbul province, i.e. the northwestern center for all triple Gravity Systems examined,

- Izmir-Denizli-Usak triangle, i.e. the southwestern center for all triple Gravity Systems examined and

- last but not least the new pole which was mentioned above as the "Gate to the East", i.e. the Kaiseri-Malatya-Adana triangle as the eastern center for all triple Gravity Systems examined (Karkazis 2012).

\section{References}

Angelis, V., \& Dimaki, C. (1998). Changes in the Attractiveness of a Geographical Region: A Survival Analysis Approach. Studies in Regional and Urban Planning, 6, 19-34.

Anemodouras, L., Hliopoulos, N., \& Koutsopetros, C. (2001). Turkey's provinces economic efficiency assessment using Data Envelopment Analysis. Department of Marketing and Operations. University of Economics \& Business, Athens.

Athanassopoulos, A, D., \& Karkazis, J. (1997). The efficiency of social and economic image projection in spatial configurations. Journal of Regional Science, 37 (1), 75-97.

Betcherman, G., Daysal, N., M., \& Pagés, C. (2010). Do employment subsidies work? Evidence from regionally targeted subsidies in Turkey. Labour Economics, 17 (4), 710-722. 
Boffey, T., B., \& Karkazis, J. (1984). P-medians and multi-medians. Journal of the Operational Research Society, 35, 57-64.

Charnes, A., Cooper, W., Lewin, A. Y., \& Seiford, L. M. (1997). Data envelopment analysis theory, methodology and applications. Journal of the Operational Research society, 48(3), 332-333.

Ciddi, S. (2009). Kemalism in Turkish politics: the Republican People's Party, secularism and nationalism. Routledge.

Eglese, R., W., \& Hendry, L., (1990). Operational Research Tutorial Papers. London: Operational Research Society.

Ferguson, Yale H. 2017. Competing Identities and Turkey's Future. European Review, 25 (1), 81-95.

Hunter, L, C., \& Graham, L., (1968). Urban worker mobility. Paris: Organisation for Economic Co-operation and Development.

Karkazis, J. (1999). The social, economic and industrial gravity centers of the Balkans. Studies in Regional \& Urban Planning, 7, 1-14.

Karkazis, J. (2007). The impact of transport cost on the European geo-economic dynamics. Journal of Transport and Shipping, 4, 53-70.

Karkazis, J., (2012). Geographic Information System. Ptolemeos-Regional Turkey. Regional \& Urban Planning, $15(1), 18-60$.

Karkazis, J., and Boffey, T. B. (1981). The multi-commodity facilities location problem. Journal of the Operational Research Society, 32, 803-814.

Karkazis, J., Baltos, G., C., \& Balodis, J. (2018). How some Seemingly Moderate Political Elections Results may Redirect a State's Historical Course, from the Top Down to the Transformation of National Growth and Socio-Cultural Development Patterns: Turkey's Political Reforms over the Last Decades as an Ideal Paradigm of Multi-Faceted National Re-Orientation. Academic Journal of Interdisciplinary Studies, 7 (1), 119-128.

Karkazis, J., and Thanassoulis, E., (1998). Assessing the effectiveness of regional development policies in Northern Greece using data envelopment analysis. Socio-Economic Planning Sciences, 32, 123-137.

Karkazis, J., Baltos, G., \& Vidakis, I. (2017). The current Turkish geopolitics as a product of personal leadership aspirations, challenging traditional methods of risk management and power measurement. Foreign Affairs: the Hellenic edition, 47, 94-115.

OECD (2017). OECD Regions at a Glance. [Online] Available: http://www.oecd-ilibrary.org/urban-ruralandregional-development/oecd-regions-at-a-glance_19990057; jsessionid=1 knjt7wsr5jd0.epsilon December, 2017)

OECD (2011). OECD Regions at a Glance 2011. Paris: Organisation for Economic Co-operation and Development/Organisation de Cooperation et de Developpement Economiques.

Oguz, I., and Pinarcioglu, M. (2006). Geographies of a silent transition: a geographically weighted regression approach to regional fertility differences in Turkey. European Journal of Population, 22 (4), 390 - 399.

Sajjad, F., and Javaid, U. (2016). The Civilizational Rift and the Idea of the Turkish Model: A Case Study (20022014). Journal of Political Studies, 23 (1), 133-156.

Stellakou, V., \& Karkazis J. (1992). Evaluation of effects of infrastructure on the long term viability of an investment. SPOUDAl, 42, 4-16.

Townroe, P, M., (1979). Industrial Movement: Experience in the US and the UK. Saxon House.

Turkish Statistical Institute (2017). Income, Living, Consumption and Poverty. [Online] Available: http://www.turkstat.gov.tr/Start.do;jsessionid=3ggrP2sXjmLF2MQmRLnLqJWInnL2LB31QH9BvJNXQW7r C2Q7xLIB!-1998769340 (21 December, 2017)

UNDP (2016). Human Development Statistics. [Online] Available: http://hdrstats.undp.org/en/tables/ (21 December, 2017)

Weiszfeld, E. (1937). Sur le point pour lequel la somme des distances de n points donnés est minimum. Tohoku Mathematical Journal, 43, 355-386. 